\title{
Molecular characterization of snuffle-causing bacterial pathogens in rabbits in terms of prevalence and pathogenicity
}

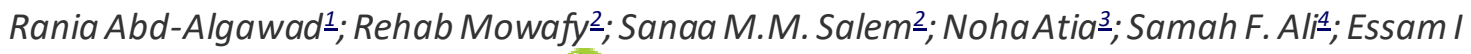

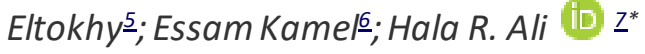 \\ Address \\ ${ }_{1}^{1}$ Mycoplasma Department, Animal Health Research Institute, Agriculture Research Center, Egypt \\ ${ }^{2}$ Pathology Department, Animal Health Research Institute, Agriculture Research Center, Egypt \\ ${ }^{3}$ Bacteriology Department, Animal Health Research Institute, Agriculture Research Center, Egypt \\ ${ }^{4}$ Bacteriology Department, Animal Health Research Institute, Agriculture Research Center, Egypt \\ ${ }^{5}$ Biotechnology Department, Animal Health Research Institute, Agriculture Research Center, Egypt \\ ${ }^{6}$ Toxicology Biochemistry Department, Animal Health Research Institute, Agriculture Research Center, Egypt \\ ${ }^{7}$ Bacteriology Department, Animal Health Research Institute, Agriculture Research Center, Egypt
}

* Corresponding author: Hala R. Ali, Email: alihala312@gmail.com

Received: 07-08-2021; Accepted: 30-10-2021; Published: 14-11-2021

doi, $10.21608 /$ ejar.2021.89555.1129

\section{ABSTRACT}

Respiratory disease, or snuffling, is a major problem associated with serious economic losses in the rabbit industry. The dis ease in rabbits is a polybacterial infection in nature, resulting from co-infection with more than one bacterial pathogen. To determine the involved bacterial pathogens in respiratory infections in terms of prevalence and pathogenicity, different specimens from rabbits with typical respiratory disorders are subjected to bacteriological examination followed by molecular verification through RT-PCR or PCR then sequencing of the PCR-product. The results identified Mycoplasma sp. as a major partner in mixed infection with virulent strains of $P$. multocida or $S$. aureus, suggesting that, initial infection with Mycoplasma sp. creates vulnerability to subsequent infection with $P$. multocida or $S$. aureus. Gross and microscopic analysis were also applied to demonstrate lesions accompanied by the detected bacterial pathogens. This study described the prevalence and characteristics of respiratory illness in rabbits domesticated in Al-Sharkia Governorate, Egypt and highlighted for the first time the role of Mycoplasma sp. in increasing the severity of rabbit-respiratory infections.

Keywords: Rabbits, Mycoplasma sp., P. multocida, S. aureus, Histopathology, RT- PCR sequencing

\section{INTRODUCTION}

Domestic rabbits are highly susceptible to developing gastrointestinal and respiratory illnesses when they are exposed to stress or extreme environmental conditions. Respiratory diseases in rabbits are second only to gastrointestinal diseases in importance, because they badly impact the rabbit industry and cause considerable economic losses (Soriano et al., 2012).

Respiratory illness in rabbits is known as snuffles, and it is recognized as a polybacterial infection caused by a combination of Pasteurella multocida with additional bacteria such as Bordetella brochiseptica, Staph. sp., Pseudomonas sp., Chlamydia sp., Acinetobacter sp., Moraxella catarrhalis and Mycoplasma sp., etc (Esther, 2003). Pasteurella multocida is one of the most frequently isolated pathogens from rabbits showing respiratory symptoms. It mainly causes upper respiratory illness (snuffles). The primary clinical symptoms of snuffles include rhinitis, sinusitis, otitis media, conjunctivitis and orchitis (Tayeb et al., 2004). Primary respiratory signs usually develop into pneumonia, septicemia and abscess in lung, because Pasteurella multocida may spread hematologically, causing acute generalized disease, fever, and sudden death. Pathological investigation may also reveal pleuropneumonia, and septicemic congestion, petechiation and microscopic abscesses throughout the viscera (Barbara and Digiacomo,2000). S. aureus is also frequently recovered from pneumonic rabbits. Induced pathogenicity usually depends on host susceptibility and bacterial virulence, where it produces lethal toxin to kill the rabbit neutrophils and suppress the host defense mechanism. A virulent strain of $\mathrm{S}$. aureus causes mastitis, pododermatitis, and subcutaneous abscesses at rabbit flock level, while infections with low virulence strains are restricted to individual rabbits (Vancraeynest et al., 2006).

Mycoplasma infection is usually asymptomatic and pathogenesis also vary according to the host and environmental factors (Schoeb et al., 1993), including co-infection with additional pathogens (Schunk et al., 1995). Mycoplasma sp. especially M. pulomins infect rat and mice causing snuffling in rats and "chattering" in mice (National Research Council, 1991). In rabbits, Mycoplasma infection is very rare; however, Barbara (2004) isolated M. pulmonis from nares and oropharynx of New Zealand white rabbits showing upper respiratory disorders. It is also previously documented the involvement of Mycoplasma in rabbit respiratory diseases. Reporting exudative bronchopneumonia and extensive foci of coagulative necrosis surrounded by inflammatory cells in naturally infected lungs with Mycoplasma while those cases of experimentally infected lungs revealed suppurative bronchiolitis and varying degrees of peribronchiolar mononuclear cell cuffing (Rodríguez et al., 1996).

The current study used multiple diagnostic approaches to determine the bacterial pathogens implicated in rabbit respiratory difficulties, as well as the most prevalent bacterial combinations of mixed infections in terms of prevalence and toxicity. It 
reports the role of Mycoplasma sp. in the development of severe respiratory illness in domestic rabbits in conjunction with either P. multocida or S. aureus.

\section{MATERIALS AND METHODS}

\section{Sampling:}

A total of 80 samples were collected from different aged and diseased rabbits from Al-Sharkia Governorate farms; 30 nasal swabs from rabbits suffering from respiratory symptoms and 50 tracheas and lungs from freshly dead ones for bacteriological examination under complete aseptic conditions. Specimens from the tracheas and lungs of the diseased rabbits, either sacrificed or freshly dead, were collected after PM examination and fixed in $10 \%$ buffered neutral formalin. Paraffin sections of 2-3-micron thickness was prepared and stained with hematoxylin and eosin stain, then examined microscopically (Survarna et al., 2013).

Bacteriological culturing:

Collected samples were inoculated on $5 \%$ sheep blood agar, MacConkey agar and mannitol salt agar then incubated at $37^{\circ} \mathrm{C}$ for $24 \mathrm{~h}$ for $P$. multocida and S. aureus isolation. Suspected colonies were initially identified by colonial morphology and Gramstaining as described by Weisburg et al. (1991) and Townsend et al. (1998).

Samples were also cultured according to Frey et al. (1968) for the presence of the fried egg colonies of Mycoplasma sp. Mycoplasma isolates identification was carried out by digitonin sensitivity test (growth inhibition) as described by Erno and Stipkovits (1973) and Razin et al. (1998). Biochemical characterization of purified Mycoplasma isolates including; glucose fermentation, arginine deamination and film \& spot formation tests were done according to Fabricant and Freundt (1967) and Watson et al. (1988).

\section{Molecular identification:}

\section{Extraction of genomic DNA:}

DNA extraction of samples was performed using the QIAamp DNA Mini kit (Qiagen, Germany, GmbH, Catalogue no.51304) following the manufacturer's recommendations.

Primers sequences and PCR amplification:

The forward primer GPO-3 (5'-GGGAGCAAACAGGATTAGATACCCT-3') and reverse primer MGSO (5'TGCACCATCTGTCACTCTGTTAACCTC-3') are part of the mycoplasma group-specific primer set. The thermal profile of the Mycoplasma $16 \mathrm{SrRNA}$ gene comprised of 40 cycles of denaturation at $94^{\circ} \mathrm{C}$ for 1 minute, annealing at $55^{\circ} \mathrm{C}$ for 1 minute, and extension at $72^{\circ} \mathrm{C}$ for 2 minutes (Van Kuppeveld et al., 1994).

All PCR reactions of Mycoplasma isolates were performed in a "Gradient Thermal cycler 1000S" (Bio - RAD, USA). The reaction mixture of total volume of $50 \mu \mathrm{l}$; was $25 \mu \mathrm{l}$ Dream Taq Green PCR Master Mix (Thermo Scientific Company, Lithuania), $5 \mu \mathrm{l}$ target DNA, $2 \mu \mathrm{l}$ of each primers (containing $10 \mathrm{pmole} / \mu \mathrm{l}$ ) and the mixture was completed by RNAse DNAse free sterile distilled water to $50 \mu \mathrm{l}$. The amplified PCR products were confirmed by using a $1.5 \%$ agarose gel, followed by UV visualization after ethidium bromide staining.

Purification and sequencing of Mycoplasma isolate:

GATC Company sequenced the PCR product using an ABI3730xI DNA sequencer and forward and reverse primers.

MegAlign, DNASTAR, Lasergene ${ }^{\circledR}$, Version 7.1.0, USA, and BioEdit sequence alignment editor (Hall, 1999). MegAlign was used to rebuild the phylogenetic tree of sequences using the neighbor-joining approach based on ClustalW. (Thomposon et al., 1994). MegAlign computed the sequence divergence and identity percent.

\section{Real-time PCR identification:}

SYBR Green real-time PCR amplification:

All real-time PCR tests were done at Biotechnology Department, Zagazig Province lab, AHRI. Two $\mu$ l of the extracted DNA was added to $18 \mu \mathrm{l}$ mastermix ( $\mathrm{Q}^{\mathrm{TM}}$ SYBR Green Supermix; Bio-Rad, USA). The mastermix contains: $10 \mu \mathrm{IQ}^{\mathrm{TM}}{ }^{\mathrm{T}}$ SYBR Green Supermix, $2 \mu \mathrm{l}$ forward and reverse primers and $6 \mu \mathrm{l}$ deionized water. The following cycling parameters were used: one cycle of $95^{\circ} \mathrm{C}$ for 5 min, $40 \mathrm{cycles}$ of $95^{\circ} \mathrm{C}$ for $10 \mathrm{sec}$ and $60^{\circ} \mathrm{C}$ for $30 \mathrm{sec}$. The fluorescence intensity of SYBR Green and the melting curve analysis were evaluated and a threshold cycle $(\mathrm{Ct})$ under 35 and a specific melting temperature $(\mathrm{Tm})$ indicated a positive result. Primers used in SYBR Green real-time PCR are shown in Table (1)

Table 1. Primers used for SYBR Green real-time PCR assays

\begin{tabular}{|c|c|c|}
\hline Target gene & Sequence (5'-3') & References \\
\hline P. multocida (sodC) & $\begin{array}{l}\text { AGTTAGTAGCGGGGTTGGCA } \\
\text { TGGTGCTGGGTGATCATCATG }\end{array}$ & Ewers et al. (2006) \\
\hline P. multocida (hgbA) & $\begin{array}{l}\text { TGGCGGATAGTCATCAAG } \\
\text { CCAAAGAACCACTACCCA }\end{array}$ & Ewers et al. (2006) \\
\hline P. multocida (nanH) & $\begin{array}{l}\text { GAATATTGGGGGGCAACA } \\
\text { ПCTCGCCCTGTCATCACT }\end{array}$ & Ewers et al. (2006) \\
\hline S. aureus (16SrRNA) & $\begin{array}{l}\text { CCTATAAGACTGGGATAACTTCGGG } \\
\text { CTTGAGTTCAACCTTGCGGTCG }\end{array}$ & Mason et al. (2001) \\
\hline Staphylococcus (ica) & $\begin{array}{l}\text { CCTAACTAACGAAAG GTAG } \\
\text { AAGATATAGCGATAAGTGC }\end{array}$ & Kumar et al. (2009) \\
\hline $\begin{array}{l}\text { Staphylococcus (spa) } \\
\text { (X-region) }\end{array}$ & $\begin{array}{l}\text { CAAGCACCAAAAGAGGAA } \\
\text { CACCAGGTTAACGACAT }\end{array}$ & $\begin{array}{l}\text { Paniagua- } \\
\text { Contreras et al. (2012) }\end{array}$ \\
\hline
\end{tabular}


Taqman Real-Time PCR amplification:

All real-time Taqman PCRs were carried out in a total volume of $20 \mu \mathrm{l}$ with $6 \mu$ I DNA template, $10 \mu \mathrm{l}$ master mix (Sensifast Probe No. Rox. Catalogue no. Bio-86050), $0.8 \mu \mathrm{l}$ of each primer, and $0.6 \mu \mathrm{l}$ of the probe(s) then the volume is completed to $20 \mu \mathrm{l}$ using deionized water. qPCR was performed on one step real-time PCR system (Thermo Fisher Scientific, Germany). The following cycling parameters were used: one cycle of $95^{\circ} \mathrm{C}$ for $5 \mathrm{~min}, 40$ cycles of $95^{\circ} \mathrm{C}$ for $10 \mathrm{sec}$ and $60^{\circ} \mathrm{C}$ for $50 \mathrm{sec}$. Cycle threshold (Ct) for each sample were calculated in comparison to positive and negative controls and the parameters of analysis were as follows: exclude early cycle $=7$, minimum relative amplifications $=0$, and minimum amplification quality $=5$. Primers and probes were purchased from Sigma-Aldrich, St. Louis, MO, USA. Primers and probes were illustrated in Table (2).

Regarding the Pasteurella isolates, amplification conditions were adjusted for the amplification of the six target genes justified as follow: Serogroups A and E in duplex, Serogroups B and D in duplex, Serogroup F, Kmt1, toxA, hgbA, sodC and nanH genes in uniplex.

Table 2. Primers and probes used for Taqman Real-Time PCR Assays.

\begin{tabular}{|c|c|c|}
\hline Target gene & Sequence (5'-3') & References \\
\hline P. multocida (Kmt1) & $\begin{array}{l}\text { ATAAGAAACGTAACTCAACATGGAAATA } \\
\text { GAGTGGGCTTGTCGGTAGTCTT } \\
\text { (FAM) AAACCGGCAAATAACAATAAGCTGA (BHQ1) }\end{array}$ & Sunaga et al. (2020) \\
\hline $\begin{array}{l}\text { P. multocida } \\
\text { serogroup A }\end{array}$ & $\begin{array}{l}\text { TCGTTAAAAATGACAGCTATGC } \\
\text { ATAATCGTCAGAAGCTCATGCG } \\
\text { (FAM) TाTCTCAGCATAACACATGATTGGAT (BHQ1) }\end{array}$ & Shikov et al. (2015) \\
\hline $\begin{array}{l}\text { P. multocida } \\
\text { serogroup B }\end{array}$ & $\begin{array}{l}\text { GCGTGTATAACCTACATCTTCCCA } \\
\text { CGTCCATCAACACCTTACTGC } \\
\text { (R6G) TAGGCACAGAATATTCAAAACCCCGT (BHQ1) }\end{array}$ & Shikov et al. (2015) \\
\hline $\begin{array}{l}\text { P. multocida } \\
\text { serogroup D }\end{array}$ & $\begin{array}{l}\text { ATCGCATCCAGAATAGCAAACTC } \\
\text { TCCGATGCTTGGTTGTGC } \\
\text { (Cy5) CGATTAAACTCAAATCTAGGGACATACTT (BHQ2) }\end{array}$ & Shikov et al. (2015) \\
\hline $\begin{array}{l}\text { P. multocida } \\
\text { serogroup E }\end{array}$ & $\begin{array}{l}\text { TGGGCACATGCTCGCTTA } \\
\text { CTGCTTGATITGTCTITCTCCTAA } \\
\text { (ROX) ATGTGGCAAAGCGATCAATTCAGA (BHQ2) }\end{array}$ & Shikov et al. (2015) \\
\hline $\begin{array}{l}\text { P. multocida } \\
\text { serogroup F }\end{array}$ & $\begin{array}{l}\text { CGGAGAACGCAGAAATCAGAA } \\
\text { CAACAACGACTTCAAATGGGTAG } \\
\text { (R6G) CTTGCTCCATTGCCAGATCATGTT (BHQ1) }\end{array}$ & Shikov et al. (2015) \\
\hline $\begin{array}{l}\text { P. multocida toxin } \\
\text { (toxA) }\end{array}$ & $\begin{array}{l}\text { GAAATGGCTGGAAAAACCAGTG } \\
\text { GAAAAGGCGCTGAAATTACTGTATC } \\
\text { (FAM) CGGCTGATTAATACGCTIGCCTTGC (BHQ1) }\end{array}$ & Sunaga et al. (2020) \\
\hline
\end{tabular}

Pathological examination:

Tissue specimens from trachea and lungs were collected from 50 freshly dead and sacrificed rabbits then fixed in $10 \%$ buffered neutral formalin. Paraffin sections 5micron thick were prepared and stained with hematoxylin and eosin stain (Survarna et al., 2013) and examined microscopically.

\section{RESULTS}

Clinical and post mortem examination:

In order to identify the bacteria involved in rabbit-respiratory diseases (snuffles), rabbits showing generalized respiratory disorders were chosen for bacteriological and microscopic examination. Most of the examined rabbits showed coughing and sneezing with serous to mucoid or purulent nasal discharge. Snuffling sound has also been observed with the affected rabbits in addition to dyspnea, depression, anorexia and high body temperature.

Postmortem examinations of sacrificed or freshly dead rabbits revealed mild to severe congestion in trachea and lung with yellowish to grey exudates in some cases. Other cases showed spongy and edematous lung while bleeding from severed surfaces was observed in some cases.

\section{Bacterial culturing:}

Sixty-eight out of the 80 examined samples including nasal swabs, tracheal and lung tissues, were positively tested for $P$. multocida, S. aureus and Mycoplasma sp. The bacteriological analysis was primarily based on the characteristic colony morphology of the isolates on specific media including the typical "fried-egg" appearance of Mycoplasma on PPLO media (Fig. S1) followed by biochemical identifications; glucose fermentation positive, arginine and film \&spot negative. The incidence rate for the three tested pathogens was approximately $85 \%$, with recovery rates of $37.5 \%, 30 \%$ and $11.25 \%$ for $P$. multocida, S. aureus and Mycoplasma sp., respectively. The results illustrated in table (3) revealed that infection process occurred either in single or mixed form and the most common bacterial combination of mixed infection was Mycoplasma sp. with S. aureus or Mycoplasma sp. with P. multocida. 
Table 3. Incidence of $P$. multocida, S. aureus and Mycoplasma sp. recovered from diseased and dead rabbits

\begin{tabular}{|c|c|c|c|c|c|c|c|}
\hline \multirow[t]{3}{*}{ Bacterial isolates } & \multicolumn{6}{|c|}{ Examined sample, $n=80$} & \multirow[t]{3}{*}{ Total } \\
\hline & \multicolumn{2}{|c|}{ Nasal swab, $n=30$} & \multicolumn{2}{|c|}{ Trachea, $\mathrm{n}=25$} & \multicolumn{2}{|c|}{ Lung, $\mathrm{n}=25$} & \\
\hline & single & Mixed & single & mixed & single & mixed & \\
\hline P. multocida & 8 & & 8 & & 10 & & 26 \\
\hline P. multocida + Mycoplasma sp. & & 0 & & 1 & & 3 & 4 \\
\hline TOTAL $P$. multocida & \multicolumn{7}{|c|}{$30(37.5 \%)$} \\
\hline S. aureus & 7 & & 4 & & 11 & & 22 \\
\hline S. aureus +Mycoplasma sp. & & 0 & & 1 & & 1 & 2 \\
\hline TOTAL S. aureus & \multicolumn{7}{|c|}{$24(30 \%)$} \\
\hline Mycoplasmasp. & 0 & & 1 & & 2 & & 3 \\
\hline Mycoplasmasp. + P. multocida & & 0 & & 1 & & 3 & 4 \\
\hline Mycoplasmasp. + S. aureus & & 0 & & 1 & & 1 & 2 \\
\hline TOTAL Mycoplasma sp. & \multicolumn{7}{|c|}{$9(11.25 \%)$} \\
\hline
\end{tabular}

Molecular identification:

Molecular identification of Mycoplasma isolates. The bacteriologically positive Mycoplasma isolates were molecularly confirmed using a standard PCR approach targeting the 16SrRNA gene to reveal a unique DNA fragment at 240bp (Fig. 1a). Furthermore, a purified Mycoplasma PCR product of the 16SrRNA gene was subjected to sequencing in both directions. The original sequence was edited to remove the indeterminate sequences that are common at the start of a sequence reaction. The sequencing results verified that the isolate is Mycoplasma sp., and the sequences were submitted to the Genbank database under the accession number "MW132895". Phylogenetic analysis of 16SrRNA sequence showed a close homology (95-100\%) with field and reference strains of Mycoplasma species on comparison and designated the rabbit isolate as "RT11-Mycoplasma sp." as shown in the (Figure 1b) \& Table (4).

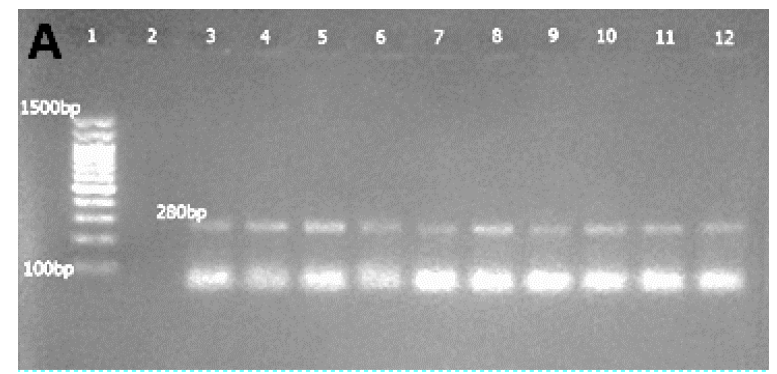

Fig. 1.A. Electrophoretic pattern of 16SrRNA gene of Mycoplasma sp. Lane (1): 100 base pair DNA ladder. Lane (2): control negative. Lane (3): control positive. Lanes (4-12): positive amplifications for target gene at 280bp.

B

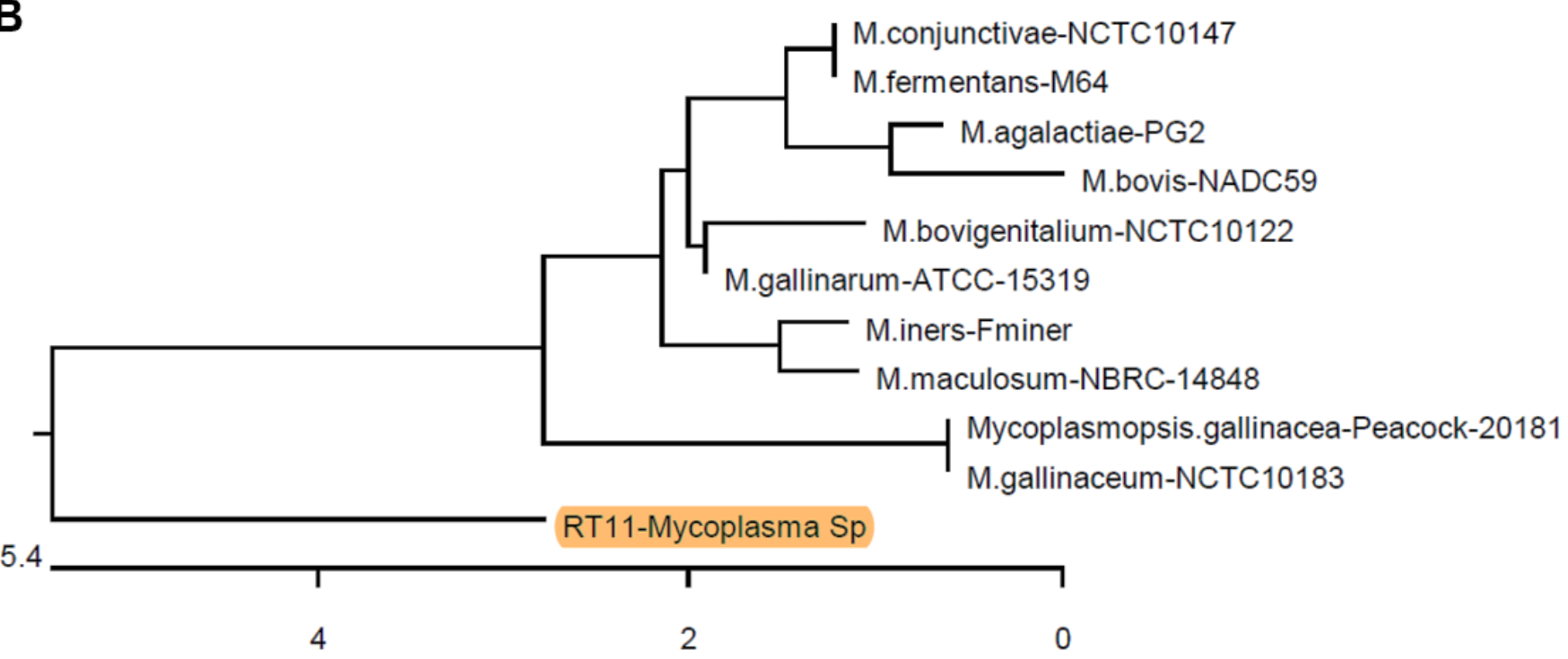

Nucleotide Substitution per 100 residues

Fig. 1.B. Phylogenetic tree of nucleotide of 16SrRNA gene of RT11-Mycoplasma sp. compared with reference and field strains 
Table 4. Identity percent of nucleotide sequencing of 16SrRNA gene of RT11-Mycoplasma sp. compared with reference and field strains

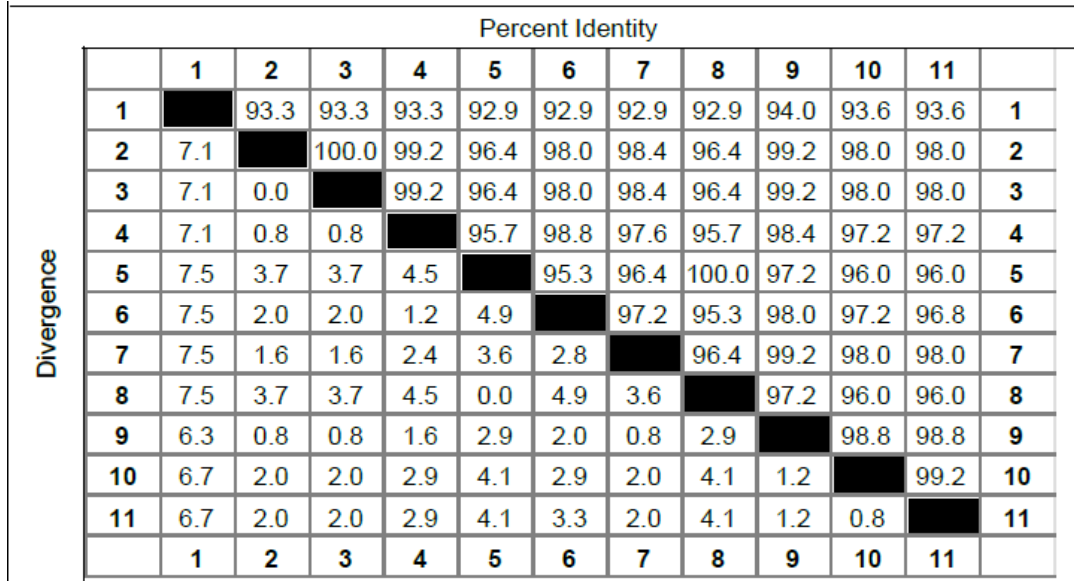

\section{RT11-Mycoplasma Sp}

M.conjunctivae-NCTC10147

M.fermentans-M64

M.agalactiae-PG2

Mycoplasmopsis.gallinacea-Peacock-20181

M.bovis-NADC59

M.bovigenitalium-NCTC10122

M.gallinaceum-NCTC10183

M.gallinarum-ATCC-15319

M.iners-Fminer

M.maculosum-NBRC-14848

Molecular identifications of Pasteurella and Staphylococcus isolates:

RT-PCR was used to test the culture positive Pasteurella isolates using Pasteurella multocida specific primers generated from the kmt1 gene. As shown in Fig. (2.a), all isolates were verified to be $P$. multocida. Multiplex PCR was subsequently utilised to determine the capsular type of $P$. multocida isolates, as shown in Fig. (2b) (Fig. 2b). Serogroup A is assigned to all isolates. Concerning Staphylococcus isolates, the positive culture result for S. aureus, including biochemical characterisation, agreed 100 percent with the RT-PCR result, which found the 16SrRNA gene in all isolates. (Fig. 2c).

Furthermore, RT-PCR is used to detect the virulence associated genes in P. multocida including sodC, hgbA and toxA (Fig. 2d-f). The distribution of the tested virulence genes is presented in Table (5), where, $100 \%$ of tested isolates were found to be positive for sodC gene, however, $h g b \mathrm{~A}$ and toxA genes were detected in $83.3 \%$ and $33.3 \%$ of the tested isolates respectively, but none of the isolates tested positive for $n a n \mathrm{H}$ gene. RT-PCR is also applied to identify spa and ica genes in $S$. aureus isolates indicating the presence of spa gene in 5 out of 7 tested isolates, while ica gene was found in all the 7 tested isolates (Fig. 2g, h) (Table 5).

Table 5. Detection of virulence genes in P. multocida and S. aureus

\begin{tabular}{|c|l|c|l|}
\hline \multicolumn{2}{|c|}{ P. multocida } & \multicolumn{2}{c|}{ S. aureus } \\
\hline No. of tested isolates (6) & Virulence genes & No. of tested isolates (7) & Virulence genes \\
\hline 3 & sodC + hgbA & 5 & spa $+i c a$ \\
\hline 2 & sodC $+h g b A+$ toxA & 2 & $i c a$ \\
\hline 1 & sodC & & \\
\hline
\end{tabular}

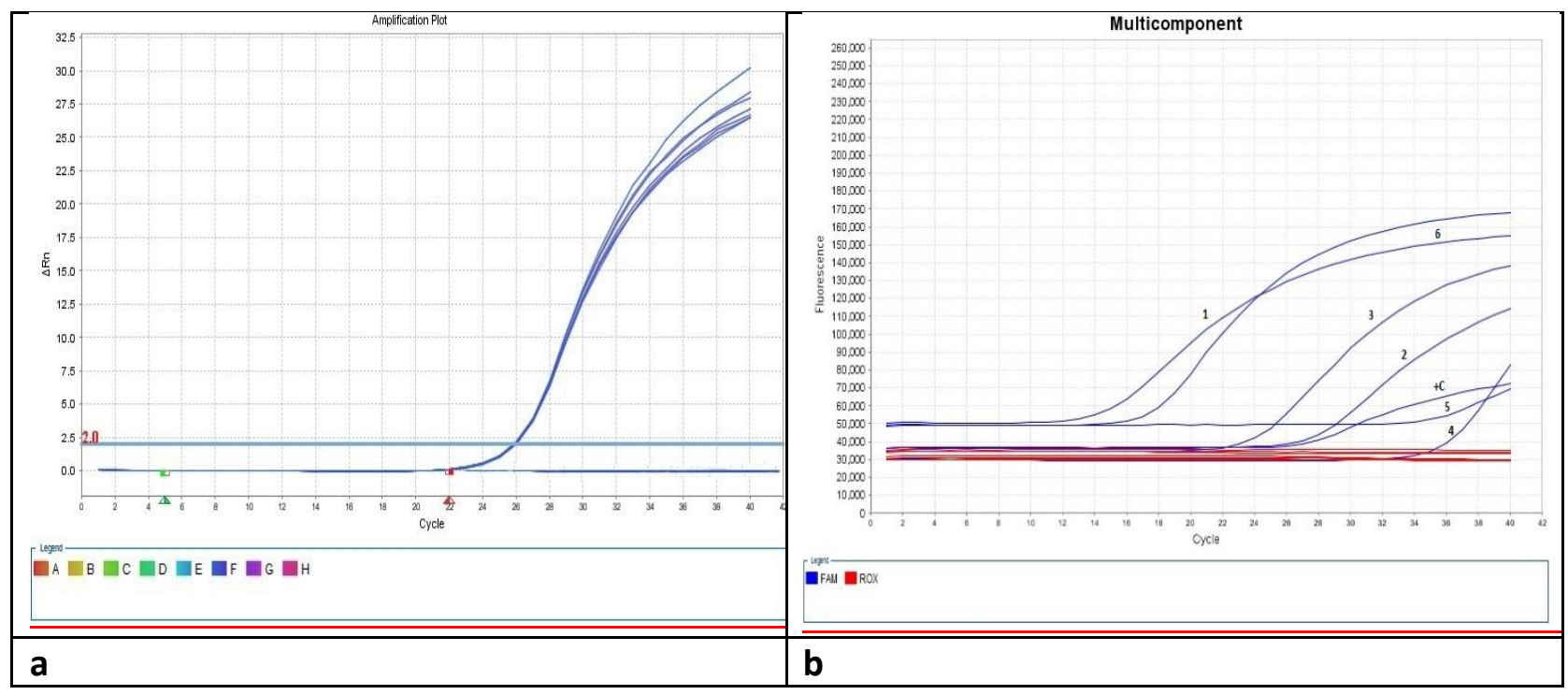




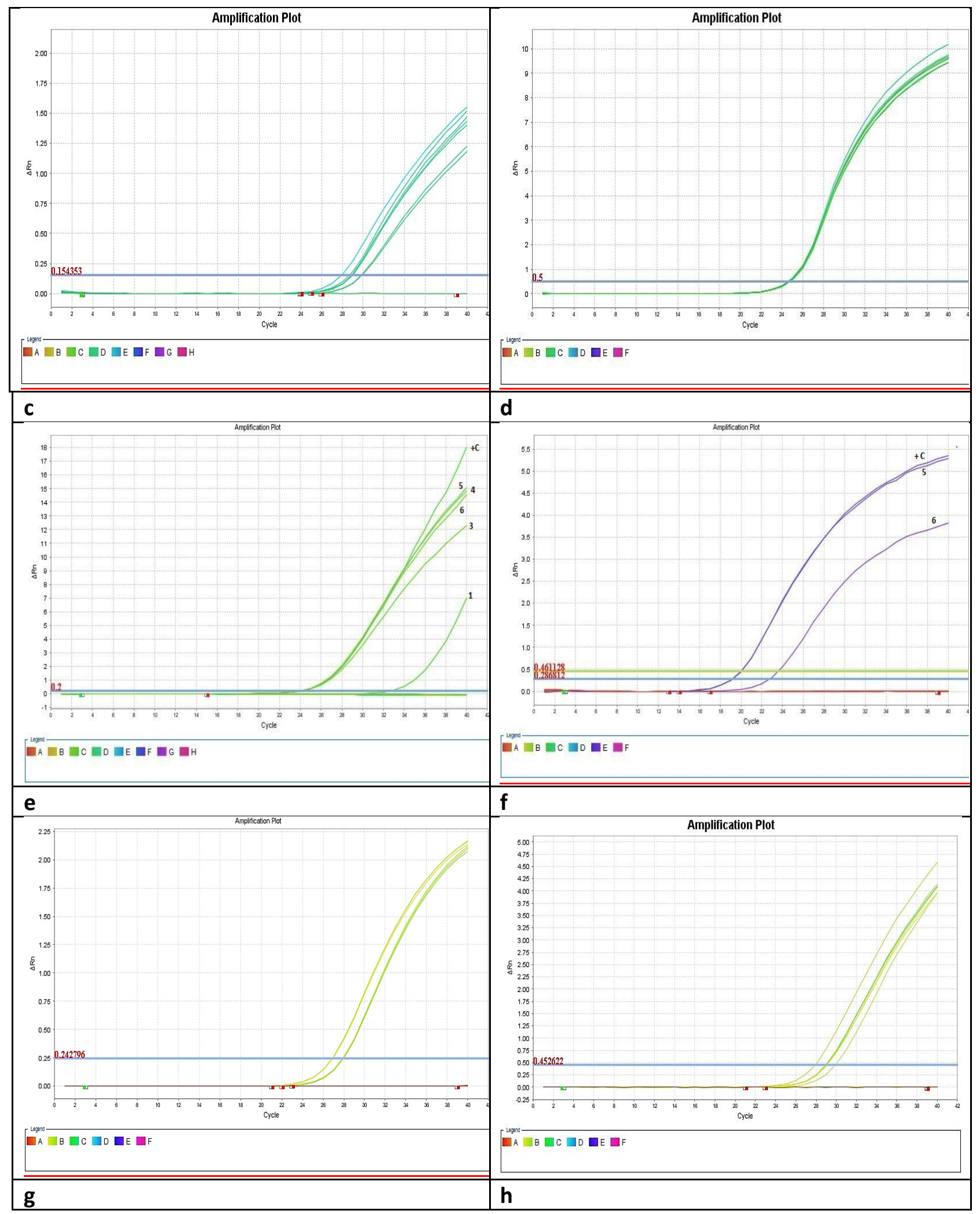

Fig. 2. PCR amplification plots identify the amplification plots that cross the threshold limits between 5 and 35 cycles as PCR-positive, where upper curves represent control postive: ${ }^{*}$. multocida (P. multocida subsp. multocida strain HN06) or S. aureus control positive (S. aureus 0402981), lower linear curves represent control negative: PCR mixture without DNA. a): Taqman RT- PCR amplification plot for Kmt1 gene among 6 tested Pasteurella isolates. b) Multiplex amplification plot obtained with a detection system based on the use of two fluorophores with 6 tested P. multocida isolates: FAM (blue line) for the detection of serogroup A, VIC (red line) for the detection of serogroup B. c): SYBR Green RT-PCR amplification plot for positive detection of 16 sRNA among 7 tested Staphylococci isolates. d): SYBR Green RT- PCR amplification plot for detecting SodC gene in 6 tested P. multocida isolates. e): SYBR Green RT-PCR amplification plot for detecting hgbA gene in $P$. multocida. f): Taqman RT- PCR amplification plot for detecting ToxA gene in 6 tested P. multocida isolates g): SYBR Green RT-PCR amplification plot for detecting spa gene in 7 tested $S$. aureus isolates. h): SYBR Green RT-PCR amplification plot detecting ica gene in 7 tested S. aureus isolates. 


\section{Microscopic findings:}

As illustrated in Table (6), the incidence and prevalence of microscopic lesions varied according to the involved etiological agent. Where, microscopic examination of trachea from rabbit with mycoplasmosis showed partial deciliation with submucosal edema (Fig. 3a) but in case of $P$. multocida, trachea showed submucosal infiltration with leukocytic cells (Fig. 3b) while, there was metaplasia of tracheal epithelial cells into goblet cells with destruction of submucosal tissue in case of $S$. aureus infection (Fig. 3c). Congestion was a common lesion reported in most infected rabbits with the aforementioned isolated microorganisms. Lung lesions also differ according to the causative agent. Lung lesions associated with mycoplasmosis include endotheliosis a nd vacuolation of tunica media in pulmonary blood vessels(Fig. 3d) and severe perivascular fibrosis with congestion (Fig. 4a), as well as, focal aggregation of lymphocytic cells (Fig. 4b).

In case of $S$. aureus infection, lung showed mild focal lymphocytic cells infiltration (Fig. 4c). While, there was diffuse emphysema and focal hemorrhage associated with most cases infected with pasteurellosis (Fig. 4d). The demonstrated lesions declared the microscopic lesions concerned with each single pathogen while those concerned with mixed ones were detailed in the lesion score (table S1). The mixed infections exaggerated the microscopic lesions showed in the single ones.
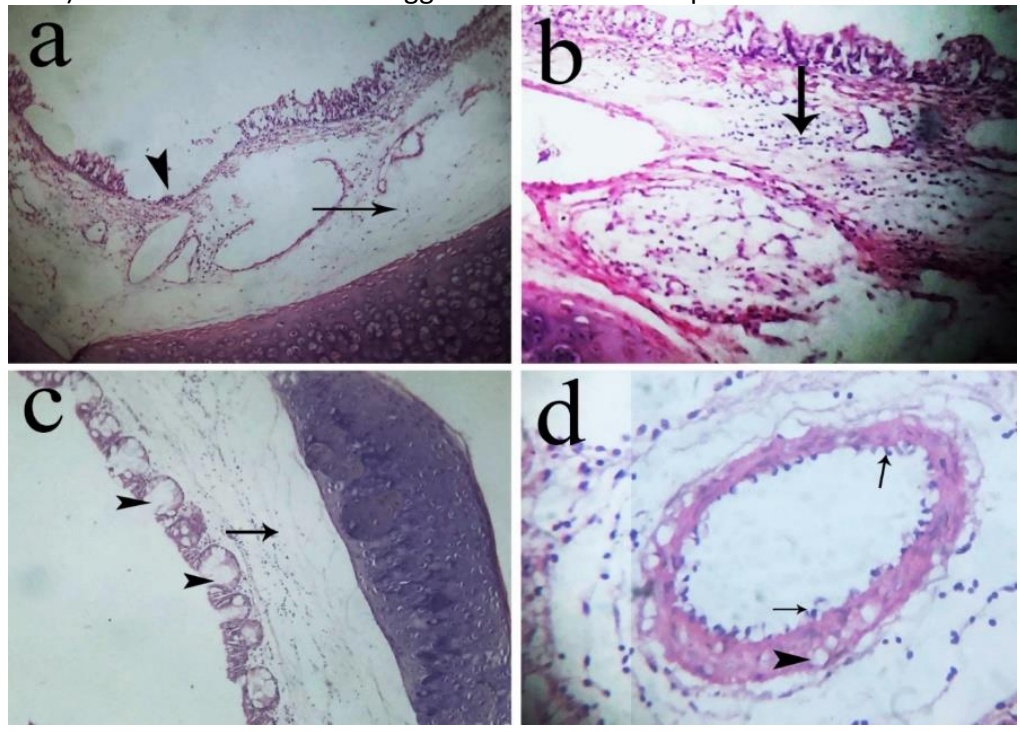

Fig. 3. Photomicrograph of trachea and lung of rabbits showing respiratory disorder (H\&E x200). a): Trachea of infected rabbit with Mycoplasma sp. showing partial deciliation (head arrow) with partial destruction of submucosa (arrow). b): Trachea of infected rabbit with $P$. multocida showing submucosal infiltration with mononuclear leukocytic cells (arrow). c): Trachea of infected rabbit with $S$. aureus showing metaplasia of epithelial cells into goblet cells (head arrows) with destruction of submucosal tissue (arrow).d): Lung of infected rabbit with Mycoplasma sp. showing endotheliosis (arrows) with vacuolation of tunica media (head arrow).

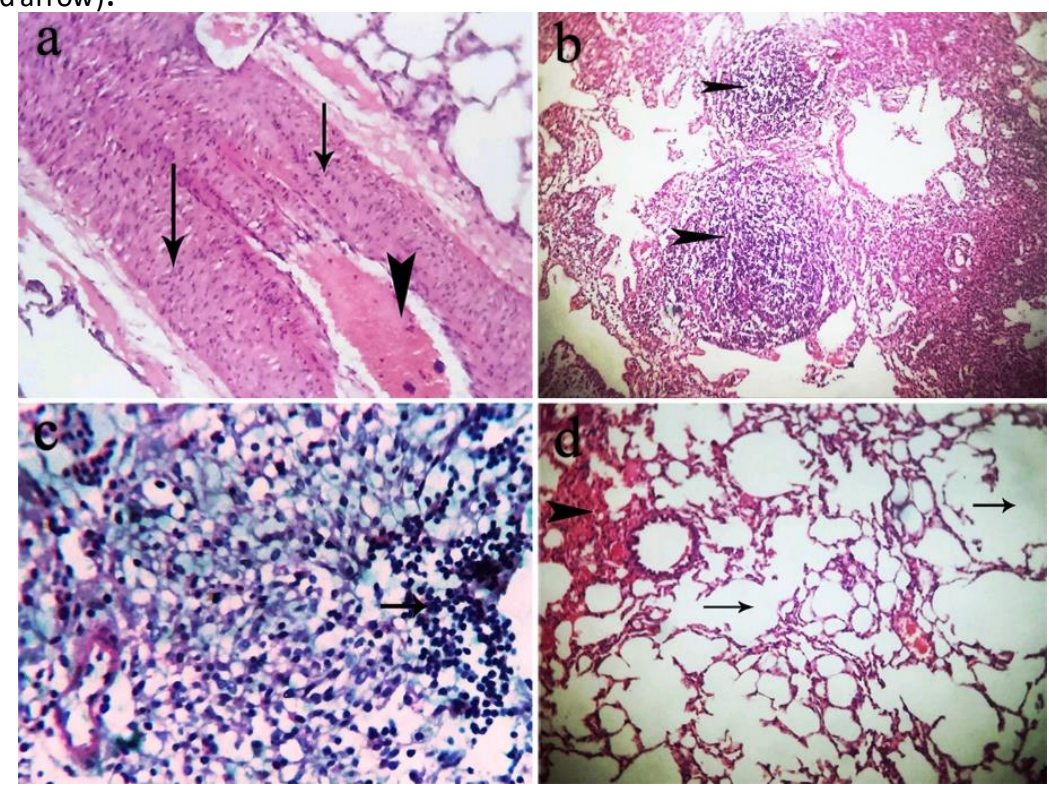

Fig. 4. Photomicrograph of trachea and lung of rabbits with respiratory disorders (H\&E x400). a) Lung of infected rabbit with Mycoplasma sp. showing perivascular fibrosis (arrows) with congestion (head arrow). b): Lung of infected rabbit with Mycoplasma sp. showing focal aggregation of lymphocytic cells (head arrow) (H\&E x200). c): Lung of infected rabbit with S. aureus showing mild focal lymphocytic cells infiltration (arrow). d) Lung of infected rabbit with $P$. multocida showing diffuse emphysema (arrows) with focal hemorrhagic areas (head arrow). 


\section{DISCUSSION}

Infections of the lungs continue to cause significant economic losses in domestic rabbits. The bacterial pathogens that are frequently isolated from affected rabbits are identified in relation to prevalence and pathogenicity in order to understand the pathogenicity of the bacteria involved in rabbit-respiratory disorders and identify the common bacterial combinations of concurrent infections and their contributions in the disease mechanisms for further control measures.

To begin, three bacterial pathogens, Mycoplasma, P. multocida, and S. aureus, were discovered to be implicated in rabbit respiratory illness based on bacteriological and molecular characterisation (snuffles). Mycoplasma pulmonis was shown to have a greater prevalence (43 percent) when co-infected with other pathogens such as Bordetella bronchiseptica, $P$. multocidia, and Staphylococcus, according to Villa et al. (2001). In rabbits with respiratory illness, these infections frequently present alone or in combination.

Regarding P. multocida, 37.5\% incidence rate was reported in accordance with Ibtesam et al. (2013) who recorded the same incidence rate of $P$. multocida from nasal swabs and lung tissues. On the other hand, Wang et al. (2019) obtained an isolation rate of $P$. multocida from lungs of dead rabbits ranged between 21.2 and $53.1 \%$, suggesting that $P$. multocida might be a major pathogen causing high mortalities in rabbit farms. The incidence rate of $S$. aureus (30\%) in our study was found in line with what described by Eid and Samir, (2018), however, a lower incidence of S. aureus is reported by Abd El-Tawab et al. (2014). In the contrary, Wang et al. (2019) demonstrated high incidence of S. aureus that reached $52.9 \%$ and led to high mortality rates and significant economic losses in nine rabbit farms.

Next, molecular techniques including PCR and RT-PCR are used for further verification of the culture results with high sensitivity and specificity (Dutta et al., 2005). Thus, in order to confirm the positive Mycoplasma culture result, a 16S rRNAbased mycoplasma group-specific PCR is used to identify the Mycoplasma isolates (Van Kuppeveld et al., 1994). Further, the PCR-product (16SrRNA gene) of one isolate was subjected to partial sequencing and phylogenetically characterized as Mycoplasma sp. The partial sequence of 16SrRNA gene generated from the rabbit isolate showed $95-100 \%$ similarity with sequences of many strains from different Mycoplasma species including $M$. conjunctiviae, $M$. agalactia, $M$. fermentans, $M$. gallinarum in comparison. Such result indicates the implication of Mycoplasma sp. in respiratory diseases in domestic rabbit. Partial sequencing based on 280bp of 16SrRNA genes was found very limited in identifying Mycoplasma species and further sequencing of the whole genome might help in specific identification of the involved Mycoplasma species.

Furthermore, RT-PCR analysis verified the detection of $P$. multocida and $S$. aureus in rabbits. All $P$. multocida isolates were also typed as serotype A using multiplex RT-PCR, in agreement with recent study that found $P$. multocida of capsular type $A$ is the predominant type associated with rabbits-respiratory disease (Massacci et al., 2018).

The pathogenicity and host specificity of different microorganisms are usually attributed to the presence of certain virulence genes that describe their epidemiology and pathogenic mechanisms. In the current study, we screened the existence of four virulence genes associated with pathogenicity of $P$. mulocida including; hemoglobin-binding proteins ( $h g b A$ ), superoxide dismutase $(\operatorname{sod} \mathrm{C})$, neuraminidase $(n a n \mathrm{H})$ and dermonecrotic toxin (toxA). Our results detected toxA in $33.3 \%$ of $P$. multocida isolates, while $h g b A$ and sodC were found in $83.3 \%$ and $100 \%$ of the examined isolates, respectively. But nanH wasn't detected in any isolates. In comparison, all isolates reported by Prajapati et al. (2020) carried sodC gene, and $37 \%$ of isolates express hgbA gene, but, $n a n \mathrm{H}$ was found in $90 \%$ of the isolates.

The virulence and pathogenicity of $S$. aureus has been linked to expression of $S$. aureus protein A (spa) and the intercellular adhesion (ica) genes (Paniagua et al., 2014). As described in an earlier study, 71.4\% of the current reported isolates carried ica and spa gene, with an increased incidence of spa gene (93.8\%) as a major virulent protein contributing to severity of respiratory infections (Bhati et al., 2016). Similarly, Abd El-Tawab et al. (2014) and Arciola et al. (2003) acknowledge the role of ica operon in synthesis of the capsular polysaccharide, which supports the cell-to-cell bacterial contacts by means of a multilayered biofilm. In contrast, ica gene has been shown to decrease in other studies (Viana et al., 2012).

In order to further our understanding of the disease pathogenicity in relation to the involved pathogens, gross and microscopic lesions are assessed, reporting variation in lesions according to the causative agent. However, common lesions of congestion and haemorrhage are reported in either single or mixed infection of the three detected bacteria. However, it is worth noting that mixed infections including Mycoplasma as a major partner resulted in exaggerated disease severity. It suggests that Mycoplasma contributes to downing the host defense mechanism, allowing P. multocida or S. aureus to establish and develop a severe form of infection in the respiratory tract of rabbits. Generally, gross lesions associated with mycoplasmosis in rabbits range from serous to supportive exudates in the nasal passages and airways in addition to a variable degree of pulmonary congestion. Similar observations were reported by Langan et al. (2000) in rabbits infected with $M$. pulmonis. The microscopic lesions currently observed with mycoplasmosis including deciliation of trachea, and edema of tracheal lamina propria, were consistent with the previous finding of Marien (2007). Endotheliosis, focal lymphocytic infiltration and leukocytic infiltration were also prominent lesions in lung of rabbits infected with Mycoplasma as a single or mixed infection. These observations were verified by George et al. (2000) who documented three distinct microscopic lesions induced by $M$. pulmonis in the airway of rodents, including neutrophil infiltration, epithelial hyperplasia, and lymphocytic hyperplasia in the lamina propria of the submucosa. We hypothesized that leukocytosis and lymphocyte infiltration may be attributed to the infection-related inflammatory condition. Our alternative hypothesis is in agreement with Pravina et al. (2010) who believed that infiltration of these cells into the infected tissues might result from apoptosis induced by bacterial toxins.

Grossly, tracheal lesions in case of $S$. aureus or P. multocida, were characterized by congestion with yellowish to greyish exudate, in consistent with what previously reported by Premalatha et al. (2009). Microscopically, lesions include congestion of tracheal and pulmonary blood vessels with leukocytic cells infiltration, as well as metaplasia of tracheal epithelial cells into goblet cells. Increased goblet cells in the respiratory epithelium either in single or mixed infections is a logical feature because goblet cells participate in the production of mucin as a host defense mechanism against infection especially in the respiratory tract (Scharfman et al., 1996). The current finding also support those of Percy et al., (1986) who noticed catarrhal trachitis in 
rabbits infected with $S$. aureus and $P$. multocida. The major detected vascular lesions including pulmonary congestion and hemorrhages were in line with observation of Cynthia. (2005) Anitha and Mammen (2013).

\section{CONCLUSION}

Finally, the findings provided in this study demonstrated for the first time the importance of Mycoplasma sp. infection, either alone or in combination with other bacterial pathogens ( $S$. aureus and $P$. multocida), in the development of severe respiratory illnesses or snuffles syndrome in rabbits. By using culture/PCR and RT-PCR techniques, the researchers were able to recover virulent strains of $S$. aureus and $P$. multocida isolates from rabbits with respiratory illnesses, suggesting the harmful impact of such bacterial infections on Egypt's rabbit industry.

Conflict of interest: No conflict of interest to declare.

The authors contribution: Authors contributed equally to the work, and the manuscript was written by Hala R. Ali.

\section{REFERENCES}

Anitha, R., \& Mammen, J. A. (2013). Histopathological lesions in pasteurellosis in an emu (Dromaius novaehollandiae)-a case report. Indian Journal of Veterinary Pathology, 37(2), 229-230.

Arciola, C. R., Campoccia, D., Gamberini, S., Donati, M. E., Baldassarri, L., \& Montanaro, L. (2003). Occurrence of ica genes for slime synthesis in a collection of Staphylococcus epidermidis strains from orthopedic prosthesis infections. Acta Orthopaedica Scandinavica, 74(5), 617-621.

Deeb, B. J. (2004). Respiratory disease and pasteurellosis. Ferrets, Rabbits, and Rodents, 172.

Deeb, B. J., \& DiGiacomo, R. E. (2000). Respiratory diseases of rabbits. Veterinary Clinics of North America: Exotic Animal Practice, 3(2), 465-480.

Bhati, T., Nathawat, P., Sharma, S. K., Yadav, R., Bishnoi, J., \& Kataria, A. K. (2016). Polymorphism in spa gene of Staphylococcus aureus from bovine subclinical mastitis. Veterinary world, 9(4), 421.

Cynthia, M. K., \& Kahn, M. (2005). The Merck veterinary manual. MERCK \& CO. INC. White house Station, NJ, USA, 151-152.

Dutta, T.K., Rajeev, Gautam, Senthil Kumar V.S. and Kotwal S.K. (2005). Diagnosis of Hemorrhagic septicemia: past, present and future. Journal Research, SKUAST J. 4:13-24.

Eid, S., \& Samir, A. H. (2018). Antimicrobial resistance attributes of staphylococci isolated from rabbits. Bioscience Research, 15(2), 862-872.

Fabricant, J., \& Freundt, E. A. (1967). Importance of extension and standardization of laboratory tests for the identification and classification of mycoplasma. Annals of the New York Academy of Sciences, 143(1), 50-58.

Frey, M. L. (1968). A medium for the isolation of avian mycoplasmas. American journal of veterinary research, 29, $2163-2171$.

Langan, G. P., Lohmiller, J. J., Swing, S. P., \& Wardrip, C. L. (2000). Respiratory diseases of rodents and rabbits. Veterinary Clinics of North America: Small Animal Practice, 30(6), 1309-1335.

Hall, T. (1999). BioEdit: a user-friendly biological sequence alignment editor and analysis program for Windows 95/98/NT. In Nucleic Acids Symptoms Series 41, 95-98.

Ibtesam M. Mazed, Eman M. Sharaf, Eman M. Zakary and Elham I. Atwa (2013). Comparison between traditional methods and real time PCR for diagnosis of Pasteurella multocida from diseased rabbits. Benha Veterinary Medical Journal 24 (1): 12-18.

Kumar, J. D., Negi, Y. K., Gaur, A., \& Khanna, D. (2009). Detection of virulence genes in Staphylococcus aureus isolated from paper currency. International Journal of Infectious Diseases, 13(6), e450-e455.

Langan, G. P., Lohmiller, J. J., Swing, S. P., \& Wardrip, C. L. (2000). Respiratory diseases of rodents and rabbits. Veterinary Clinics of North America: Small Animal Practice, 30(6), 1309-1335.

Marien, M. (2007). Mixed respiratory infections in turkeys, with emphasis on avian metapneumovirus, Ornithobacterium rhinotracheale, Escherichia coli and Mycoplasma gallisepticum (Doctoral dissertation, Ghent University).

Massacci, F. R., Magistrali, C. F., Cucco, L., Curcio, L., Bano, L., Mangili, P., ... \& Christensen, H. (2018). Characterization of Pasteurella multocida involved in rabbit infections. Veterinary Microbiology, 213, 66-72.

National Research Council. (1991). Infectious diseases of mice and rats.

Paniagua-Contreras, G., Sáinz-Espu, T., Monroy-Pérez, E., Rodríguez-Moctezuma, J. R., Arenas-Aranda, D., Negrete-Abascal, E., \& Vaca, S. (2012). Virulence markers in Staphylococcus aureus strains isolated from hemodialysis catheters of Mexican patients. 2, 476-487.

Paniagua-Contreras, G. L., Monroy-Pérez, E., Vaca-Paniagua, F., Rodríguez-Moctezuma, J. R., Negrete-Abascal, E., \& Vaca, S. (2014). Implementation of a novel in vitro model of infection of reconstituted human epithelium for expression of virulence genes in methicillin-resistant Staphylococcus aureus strains isolated from catheter-related infections in Mexico. Annals of clinical Microbiology and Antimicrobials, 13(1), 1-9.

Percy, D. H., Bhasin, J. L., \& Rosendal, S. (1986). Experimental pneumonia in rabbits inoculated with strains of Pasteurella multocida. Canadian Journal of Veterinary Research, 50(1), 36.

Prajapati, A., Chanda, M. M., Yogisharadhya, R., Parveen, A., Ummer, J., Dhayalan, A., ... \& Shivachandra, S. B. (2020). Comparative genetic diversity analysis based on virulence and repetitive genes profiling of circulating Pasteurella multocida isolates from animal hosts. Infection, Genetics and Evolution, 85, 104564.

Premalatha, N., Kumar, K. S., Purushothaman, V., Ravikumar, G., \& Muralimanohar, B. (2009). Incidence of Pasteurellosis (snuffles) in a rabbit farm. Tamilnadu Journal of Veterinary and Animal Sciences, 5(6), 269-271.

Razin, S., Yogev, D., \& Naot, Y. (1998). Molecular biology and pathogenicity of mycoplasmas. Microbiology and molecular biology Reviews, 62(4), 1094-1156. 
El Tayeb, A. B., Morishita, T. Y., \& Angrick, E. J. (2004). Evaluation of Pasteurella multocida isolated from rabbits by capsular typing, somatic serotyping, and restriction endonuclease analysis. Journal of veterinary diagnostic investigation: official publication of the American Association of Veterinary Laboratory Diagnosticians, Inc, 16(2), 121-125.

Townsend, K. M., Frost, A. J., Lee, C. W., Papadimitriou, J. M., \& Dawkins, H. J. (1998). Development of PCR assays for speci esand type-specific identification of Pasteurella multocida isolates. Journal of Clinical Microbiology, 36(4), 1096-1100.

Scharfman, A., Kroczynski, H., Carnoy, C., Van Brussel, E. D. W. I. G. E., Lamblin, G., Ramphal, R., \& Roussel, P. (1996). Adhesion of Pseudomonas aeruginosa to respiratory mucins and expression of mucin-binding proteins are increased by limiting iron during growth. Infection and Immunity, 64(12), 5417-5420.

Schoeb, T. R., Juliana, M. M., Nichols, P. W., Davis, J. K., \& Lindsey, J. R. (1993). Effects of viral and mycoplasmal infections, ammonia exposure, vitamin A deficiency, host age, and organism strain on adherence of Mycoplasma pulmonis in cultured rat tracheas. Laboratory Animal Science, 43(5), 417-424.

Shikov, A.N., Ternovoy, V.A., Nefedchenko, A.V., Glotova, T.I., Glotov, A.G., Sergeev, A.N., and Agafonov, A.P. (2015). Set of oligonucleotide primers and fluorescent-labeled probes for identification and subtyping of DNA of bacteria Pasteurella multocida serotypes A, B, D, E, F by PCR in real time. Patent number RU2551958C1

Soriano-Vargas, E., Vega-Sánchez, V., Zamora-Espinosa, J. L., Acosta-Dibarrat, J., Aguilar-Romero, F., \& Negrete-Abascal, E. (2012). Identification of Pasteurella multocida capsular types isolated from rabbits and other domestic animals in Mexico with respiratory diseases. Tropical Animal Health and Production, 44(5), 935-937.

Vancraeynest, D., Haesebrouck, F., Deplano, A., Denis, O., Godard, C., Wildemauwe, C., \& Hermans, K. (2006). International dissemination of a high virulence rabbit Staphylococcus aureus clone. Journal of Veterinary Medicine, Series B, 53(9), 418-422.

Van Kuppeveld, F. J., Johansson, K. E., Galama, J. M., Kissing, J., Bölske, G., Van der Logt, J. T., \& Melchers, W. J. (1994) . Detection of mycoplasma contamination in cell cultures by a mycoplasma group-specific PCR. Applied and Environmental Microbiology, 60(1), 149-152.

Villa, A., Gracia, E., Fernandez, A., Albizu, I., \& Baselga, R. (2001). Detection of mycoplasmas in the lungs of rabbits with respiratory disease. The Veterinary Record, 148(25), 788-789.

Wang, J., Sang, L., Sun, S., Chen, Y., Chen, D., \& Xie, X. (2019). Characterisation of Staphylococcus aureus isolated from rabbits in Fujian, China. Epidemiology and Infection, 147.

Watson, H. L., McDaniel, L. S., Blalock, D. K., Fallon, M. T., \& Cassell, G. H. (1988). Heterogeneity am ong strains and a high rate of variation within strains of a major surface antigen of Mycoplasma pulmonis. Infection and Immunity, 56(5), 13581363.

Weisburg, W. G., Barns, S. M., Pelletier, D. A., \& Lane, D. J. (1991). 16S ribosomal DNA amplification for phylogenetic study. Journal of Bacteriology, 173(2), 697-703.

Copyright: @ 2021 by the authors. Licensee EJAR, EKB, Egypt. EJAR offers immediate open access to its material on the grounds that making research accessible freely to the public facilitates a more global knowledge exchange. Users can read, download, copy, distribute, print or share a link to the complete text of the application under Creative Commons BY-NC-SA 4.0 International License. 


\section{التوصيف الجزيئي لمسببات الأمراض البكتيرية المسببة للشخير في الأرانب من حيث الانتشار والإمراضية الإيكة}

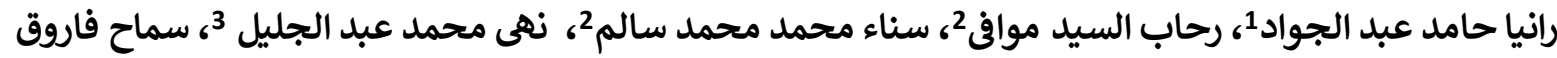

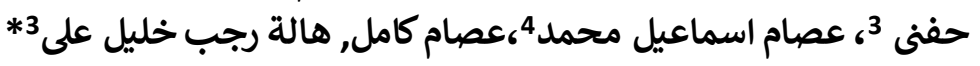

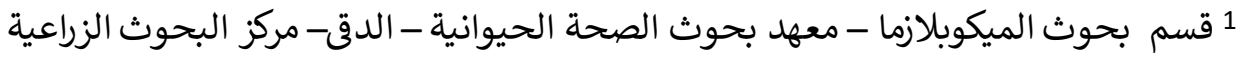

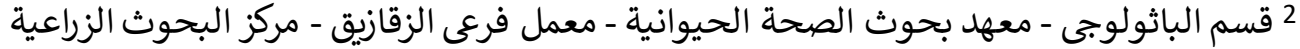

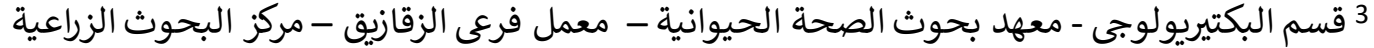

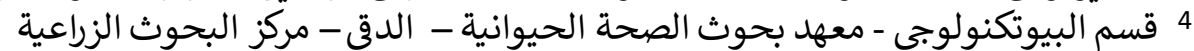

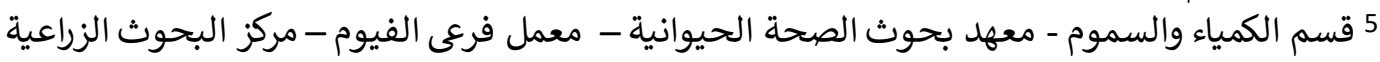

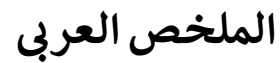

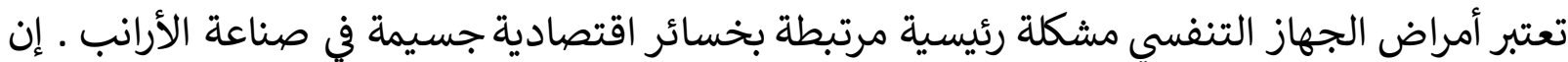

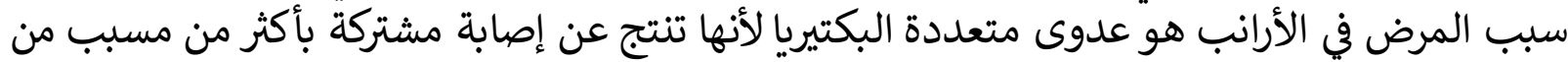

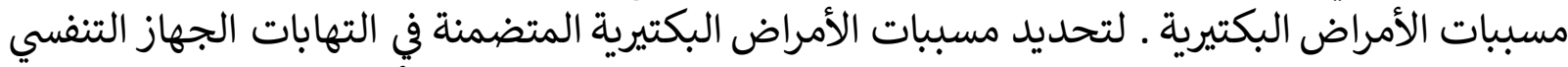

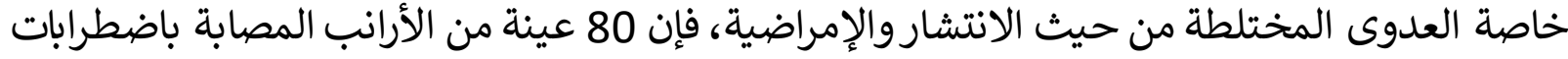

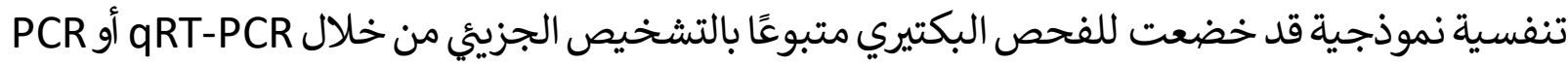

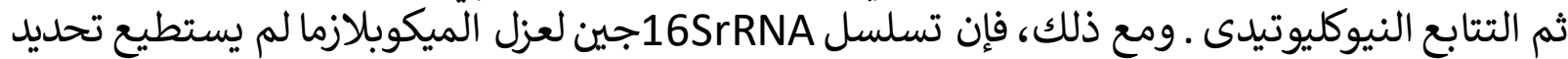

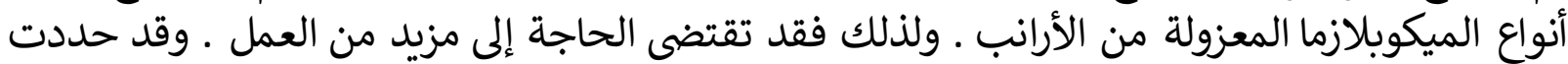

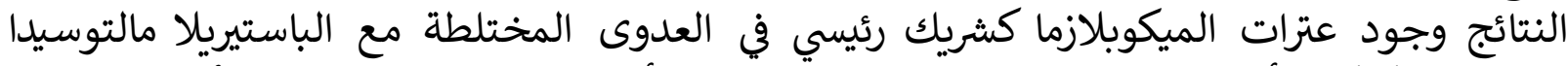

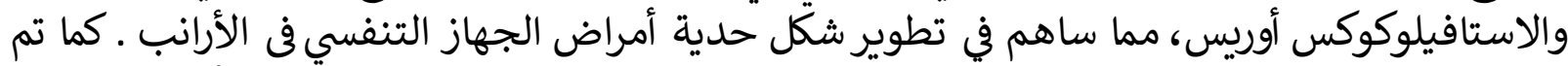

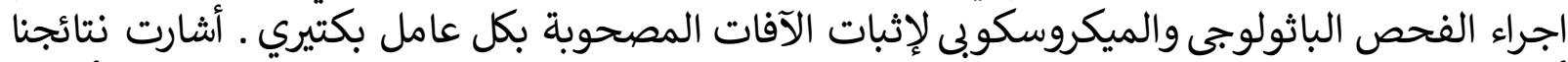

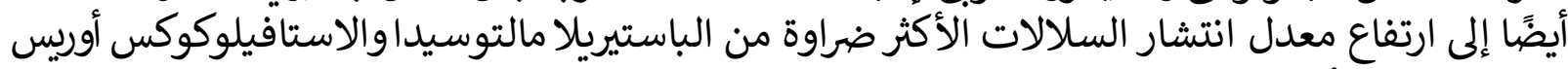

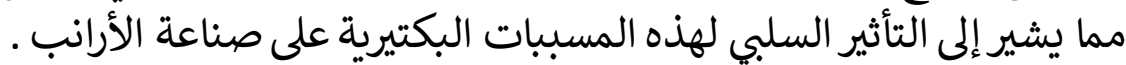

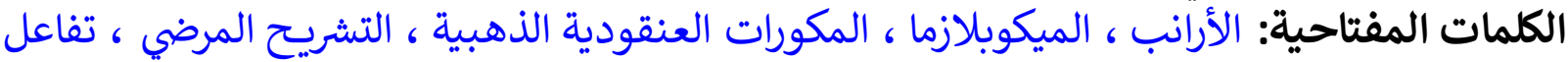

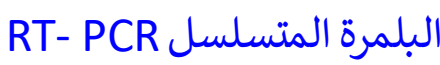

